\title{
Local Markets: Agrobiodiversity Reservoirs and Access Points for Farmers' Plant Propagation Materials
}

\author{
Claudia Heindorf ${ }^{1 *}$, Juan Antonio Reyes-Agüero ${ }^{2}$ and Anuschka van't Hooft ${ }^{3+}$ \\ ${ }^{1}$ Multidisciplinary Postgraduate Program for Environmental Sciences, Autonomous University of San Luis Potosí, San Luis \\ Potosí, Mexico, ${ }^{2}$ Desert Zone Research Institute, Autonomous University of San Luis Potosí, San Luis Potosí, Mexico, \\ ${ }^{3}$ Faculty of Social Sciences and Humanities, Autonomous University of San Luis Potosí, San Luis Potosí, Mexico
}

OPEN ACCESS

Edited by:

Barbara Gemmill-Herren,

Prescott College, United States

Reviewed by:

Durgesh K. Jaiswal,

Banaras Hindu University, India

Luciana Porter-Bolland,

Instituto de Ecología (INECOL), Mexico

*Correspondence:

Claudia Heindor

claudia.heindorf@tutanota.com

${ }^{\dagger}$ Anuschka van't Hooft orcid.org/0000-0002-3742-9121

Specialty section:

This article was submitted to Agroecology and Ecosystem Services, a section of the journal Frontiers in Sustainable Food Systems

Received: 22 August 2020 Accepted: 11 January 2021

Published: 11 February 2021

Citation: Heindorf C, Reyes-Agüero JA and van't Hooft $A$ (2021) Local Markets: Agrobiodiversity Reservoirs and Access Points for Farmers' Plant Propagation Materials.

Front. Sustain. Food Syst. 5:597822. doi: 10.3389/fsufs.2021.597822
Local markets are access points to local agrobiodiversity and to part of the informal seed systems on which most small-scale farmers worldwide depend. With the urgent need for more sustainable food systems, detailed studies of the food plant diversity in local markets contribute to a better understanding of the role of local markets in a functioning rural food system. In particular, the products that farmers trade and also use for plant propagation are of interest, i.e., seeds and other propagules such as cuttings, pseudostems, rhizomes, or tubers purposes, since they represent our genetic capital for food production. This study aims to show the role of local markets as access points for plant propagation materials and their contribution to regional in situ conservation of local food plant resources. We analyzed the inter- and intra-specific food plant diversity of the products from local merchants in 10 markets in the agrobiodiversity rich region of the Huasteca Potosina, Mexico. We recorded 275 different food plants consisting of 99 plant species, which have a high intraspecific richness of 210 variants. The list includes 58 species that are useful for propagation. The average number of variants suitable for propagation at each market is 58.4. The results show that the different richness parameters vary within and between the inventoried markets. They correlate partially to different factors like market size and origin. We conclude that local markets in the Huasteca Potosina are important components of the rural food system by providing access to a great variety of local food plants, as well as to seeds and other propagation materials for farming. However, diversity may be threatened, because of the high average proportion of unique and rare food plants $(63.5 \%)$ in the markets. Also, almost half $(45.1 \%)$ of the total richness is present in $<1 \%$ of the inventoried stands. Political actions are needed to maintain and promote the use and conservation of this diversity in the future.

Keywords: agrobiodiversity, food plant diversity, plant genetic resources, seed network, seed access, Indigenous people, local markets

\section{INTRODUCTION}

Markets have always been places of gathering. In Mexico, some traditional farmer markets or tianguis (from Nahuatl tiankistli) date back to pre-Hispanic times when long-distance traders and their human carriers traveled across multiple regions, providing access to natural resources from different ecological zones. The economic activities at these markets involve cultural exchange, based 
on traditional knowledge, of products with commercial value and social significance. As such, tianguis or local markets were and still are "strategic focal points for evaluating society, economy and production systems which impact the relationship between plants and people" (Linares and Bye, 2016; Colin-Bahena et al., 2018).

Local and regional tianguis are places where small-scale farmers market their surplus produce. Contrary to big food supply chains and supermarkets that have become the main places to purchase food in the modern food system, local markets form a vital part of the traditional food system and are important food sources for the rural population (Maxwell and Slater, 2003; Ericksen, 2008). Local markets contribute to food sovereignty by providing access to local and regional food plants produced by small-scale farmers who apply traditional management practices. These practices promote associated biodiversity in the agricultural landscapes (see Chappell et al., 2013; Fanzo et al., 2013).

Local markets also function as access points and distribution centers for local plants and seeds (FAO, 2012; McGuire and Sperling, 2016). They are the principal sources for seeds and planting materials from outside the smallholders' communities and for some crops they even represent the most important supply source (e.g., FAO, 2016; Kansiime and Mastenbroek, 2016). Local markets become even more important during stress periods that cause shortages in farmers' seed stock and in the supply from social networks (Kansiime and Mastenbroek, 2016). Furthermore, they offer a wide range of plants and seeds from different farming communities in a centralized place, which promotes local and regional seed and plant flow, and makes them especially important as seed sources in a situation of postcrisis (McGuire and Sperling, 2013). However, local markets are neglected in seed system literature. The use of planting material from local markets is not sufficiently acknowledged in formal research and the seed sectors (Sperling et al., 2020).

Two main groups of seed supply systems exist: the formal and informal or traditional systems. The formal seed sector consists of improved and certified seeds produced by scientific breeders and distributed by private companies or through governmental interventions. The informal seed sector includes mainly local varieties, which are saved and distributed through farmers' social networks and local markets (FAO, 2016). The informal seed sector still plays an important role in seed access and distribution in the developing world, especially for the 475 million small farms ( $<2 \mathrm{ha})$ that belong to family farmers of a total of 570 million farms worldwide (Lowder et al., 2014). Different studies show that most farmers (75-90\%) in the Global South depend primarily on seed and planting materials from the informal seed system (Almekinders et al., 1994; Sperling and McGuire, 2010; Poudel et al., 2015), as they obtain seed and planting materials from their own stock or from neighbors, relatives, and local marketplaces. Farmer seed circulation networks, which include local markets, facilitate access to new varieties and landraces (McGuire and Sperling, 2016). Since the beginning of agriculture, trading networks enable the dissemination of new crops, and their related technical knowledge. They even boost domestication processes, e.g., those reported for the case of Nubian cotton, when the Roman trade of cotton from India encouraged Nubian farmers to domesticate their own local cotton (Van der Veen, 2011; Meyer et al., 2012).

Fostering agroecological development and promoting the transition processes to more sustainable agricultural production involves access to local seed sources (Sperling and McGuire, 2010). Next to conditions such as access to agroecological knowledge, access to land, governmental support, and solidarity markets (FAO, 2018b; Anderson et al., 2019), agroecological transformation and scaling depend on native or local seeds as a non-replaceable good linked to multiple dimensions of the agroecosystem (Chable et al., 2020). One main advantage of autochthonous plant propagation resources is their optimal fitting to the local cultural and environmental setting with its particular biotic and abiotic conditions because they were keenly selected over time and coevolved with farmers' needs and preferences (Cleveland et al., 1994). A further advantage is the propagation of these local seeds and plants by the farmers themselves. This strengthens farmers' seed sovereignty, autonomy, and flexibility in decision making, while at the same time reducing their dependence on external inputs like new seed materials, fertilizers, and chemicals for pest control (Cleveland et al., 1994; Adhikari, 2014). The use of local seeds contributes to the conservation and evolution of traditional knowledge on farming management practices but also of the preparation and processing of traditional foods and beverages. Traditional food plant diversity keeps agroecological knowledge vivid and evolving. In sum, local plant materials and seeds are the fuel for social-ecological networks in agricultural societies in which agroecology is practiced, which is necessary for agroecological scaling (García López et al., 2019).

Mexico counts over four million family farms, representing $78.6 \%$ of the total agricultural production units. Most of these family farms $(73.0 \%)$ are dedicated to agricultural production. Here, Indigenous and other small-scale farmers manage a high diversity of food plants in integrated agricultural-forestry systems, mainly providing subsistence diets (Altieri, 2002). Farmer and community-based seeds still play a central role in these agricultural-forestry systems, even when the country has an advanced formal seed development and supply system. Formally certified seed supply is mainly limited to some selected key crops like maize and bean. Commercial seeds are often not well accepted by the local farmers as they show a weaker performance regarding adaptation to local environmental conditions and management practices. Also, they are considered to have a less favorable taste and flavor (Bellon, 1996; Louwaars and de Boef, 2012; Coomes et al., 2015).

Despite the cultural importance and the diversity of products offered in the local markets, detailed inventories of market products are scarce and focus on medicinal plants and some selected food groups (e.g., Martínez-Moreno et al., 2006; Hernández-Rico and Moreno-Fuentes, 2010; Juárez Hernández et al., 2014). In Mexico, but also worldwide, complete and recent surveys that include information on intraspecific diversity in local markets are still missing. This hinders the understanding of "the role of these markets" in the access to food plant diversity in general and to plant propagation resources. 


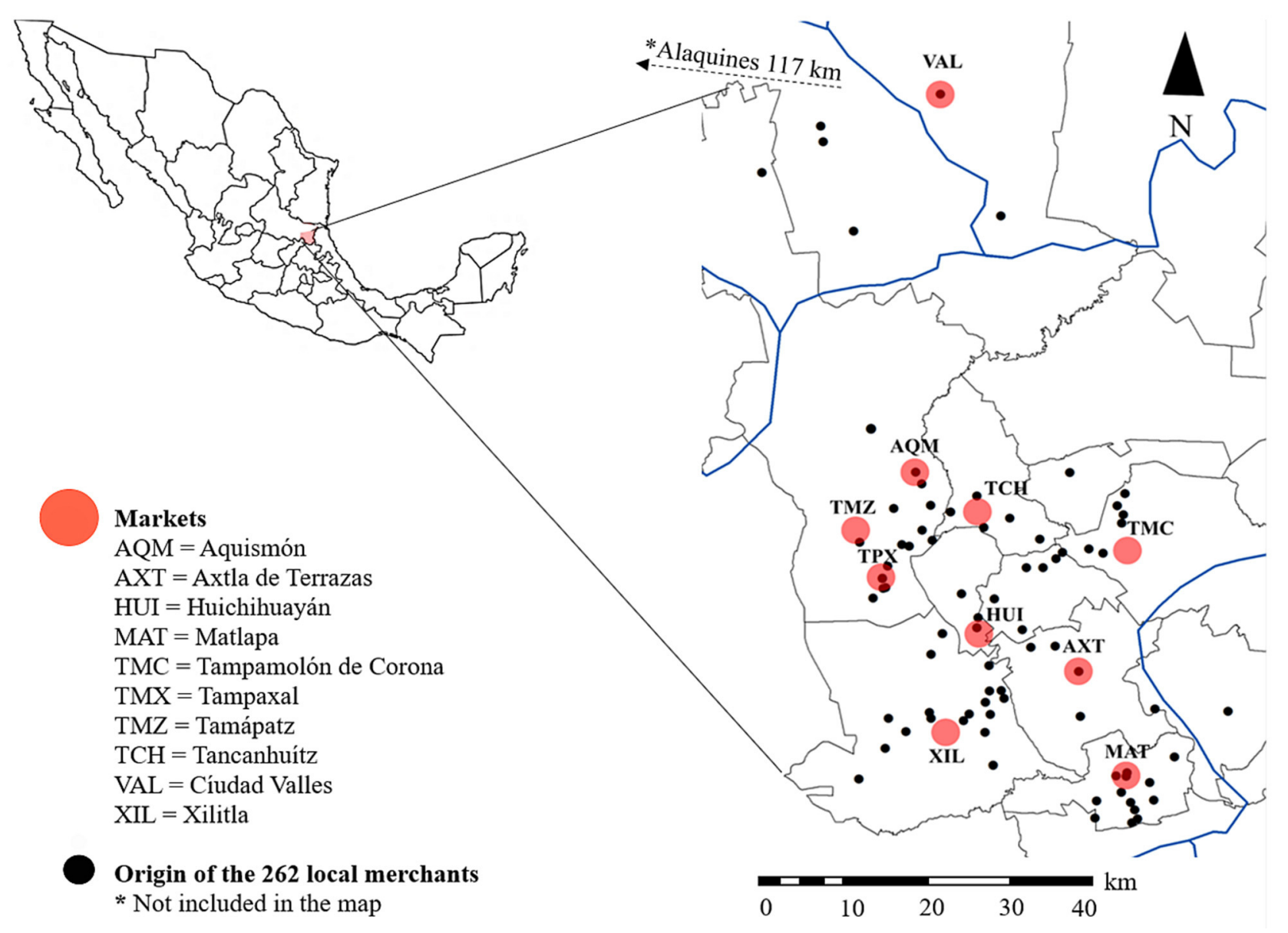

FIGURE 1 | Location of the markets in the Huasteca Potosina included in this study and the communities of origin of the local merchants.

This study investigates the contribution of rural markets to the use and in situ conservation of local food plant resources. Local food plant resources include native and non-native food plant species, as both are part of the local diet and traditional knowledge system. Based on a case study, we show the reservoir of food plants on the tianguis in the Huasteca Potosina, Mexico, displaying their role as an important supply source of planting materials and seeds for local farmers. We analyzed the interand intraspecific food crop diversity of the commercialized products in 10 local markets. By "products," we mean food plant species and variants that are merchandised in their complete natural form or parts (seeds, leaves, and fruits). We did not include processed foods. Emphasis was put on food plant propagation resources.

\section{METHODS}

\section{Site Selection and Data Collection}

For this study, we selected 10 local rural markets mentioned as important seed sources by key informant farmers in a previous study (Heindorf et al., 2019). All these local markets are situated in the Huasteca Potosina region in the southeastern part of the federal state of San Luis Potosí in Mexico (Figure 1). The Huasteca Potosina is an environmentally heterogeneous tropical mountainous region covering different vegetation types (Table 1). Most small-scale farmers in the Huasteca Potosina apply traditional management practices and manage a highly diverse agroecosystem. They usually do not depend on external inputs like fertilizers, pest control, or machinery but manage their agroecosystem based on agroecological methods and traditional knowledge. The use of native seeds is predominant (Heindorf et al., 2019).

Most of the markets included in the study belong to municipalities where the population is predominantly of Tének (Huastec Mayan) origin, yet marketplaces are arenas for social interaction between members of various ethnic groups (Table 1). Due to the seasonal effect in the variety of products, each of the 10 markets was visited twice, the first time during the rainy season (mainly May-August) and again at the end of the rainy season and the beginning of the dry season (mainly in November-May). At each market, all stands were counted and assigned to different stand types depending on the product category offered (e.g., fruits and vegetables, medicinal and ornamental plants, fish and seafood). In our study, a stand is a spot where people sell their 
TABLE 1 | Characteristics of the research sites.

\begin{tabular}{|c|c|}
\hline Markets inventoried & $\begin{array}{l}\text { Ten local rural markets: } \\
\text { AQM, Aquismón; AXT, Axtla de Terrazas; HUI, } \\
\text { Huichihuayán; MAT, Matlapa; TMZ, Tamápatz; } \\
\text { TMC, Tampamolón de Corona; TMX, } \\
\text { Tampaxal; TCH, Tancanhuitz; VAL, Ciudad } \\
\text { Valles; XIL, Xilitla. }\end{array}$ \\
\hline \multirow[t]{2}{*}{$\begin{array}{l}\text { Distance between the } \\
\text { markets }\end{array}$} & $\begin{array}{l}\text { From North to South: } 92 \text { km. (Ciudad } \\
\text { Valles-Matlapa) }\end{array}$ \\
\hline & $\begin{array}{l}\text { From West to East: } 47 \text { km. } \\
\text { (Tamápatz-Tampamolón de Corona) }\end{array}$ \\
\hline \multirow[t]{3}{*}{$\begin{array}{l}\text { Dominant potential } \\
\text { vegetation types (altitude) }\end{array}$} & $\begin{array}{l}\text { Tropical deciduous forest }(0-300 \mathrm{~m}) \\
\text { Tropical rainforest }(300-800 \mathrm{~m})\end{array}$ \\
\hline & Cloud forest (800-1,200 m), and \\
\hline & Oak and pine forest (>1,200 m) \\
\hline Ethnic groups & $\begin{array}{l}\text { Tének (main ethnic group), Nahua, and Xi'iuy, } \\
\text { and non-Indigenous population }\end{array}$ \\
\hline \multirow[t]{3}{*}{ Land use systems } & Milpas (polyculture maize fields) \\
\hline & Cañaverales (sugarcane fields) \\
\hline & $\begin{array}{l}\text { Agroforestry systems: Fincas (plantations that } \\
\text { focus on coffee production), Te'loms* (patches } \\
\text { of agroforestry systems inside the forest and } \\
\text { mixed with perennial and semi-perennial } \\
\text { crops), Home gardens (agroforestry systems } \\
\text { around the housing complex), Huertas (fruit } \\
\text { tree plantations) }\end{array}$ \\
\hline $\begin{array}{l}\text { Local merchants } \\
\text { interviewed }\end{array}$ & $\begin{array}{l}262 \text { (most of them Tének); they live in the } \\
\text { communities close to the local markets and sell } \\
\text { locally produced fruits and vegetables. One } \\
\text { local merchant is equal as one local stand. }\end{array}$ \\
\hline Non-local merchants & $\begin{array}{l}\text { Not included in this study; they sell products } \\
\text { from outside the region. }\end{array}$ \\
\hline
\end{tabular}

*Tének name.

products, which can be either a formal market stall, a place on the ground, or in the streets.

As the research focused on the rural markets as access points to local seed and plant variants, we included only local merchants and their products in this study. By local merchants, we refer to people from the surrounding rural communities who offer fruits and vegetables cultivated in their managed agroecosystem complex. Some offer the products from other farmers of their communities as well. Also, they may resell regional products purchased in urban centers. By non-local merchants, we refer to people who sell mainly food and products produced outside the region. Most of the non-local merchants do not live in the surrounding rural communities. Local merchants usually cannot afford to rent fixed market stalls with furniture to accommodate their products (Table 1, Figure 2). Instead, they display their products on wooden boxes or blankets on the ground or walk around to offer their merchandise (Pérez Castro, 2005). After a random selection process, we inventoried $63.3 \%(\mathrm{SD}=17.6)$ of these stands or selling points.

We interviewed 262 local merchants to obtain general sociodemographic data and information on the origin of their products. We recorded the edible inter- and intraspecific food plant diversity of each of their stands, together with the local names and descriptions. Local collaborators accompanied us during the market visits and interviews, as they are acquainted with local varietal descriptors and have expert knowledge on local food plant diversity. In several cases, interviews were exclusively held in Tének because local merchants were more familiar and at ease with their Indigenous language.

For some key crops in the region, planting material is not available at the local markets (e.g., banana cuttings). Likewise, not all food plants at these markets serve as propagation materials (Sperling, 2008). To show the contribution of local markets in the procurement of seeds and plant products and information about the suitability as plant propagation materials, we considered data from our main research project with 33 local farmers about the used plant propagation materials and the provenance of more than 1,700 inventoried food plants and their variants (Heindorf et al., 2019, in preparation).

\section{Data Analysis}

Our data on food plant diversity from the local merchants comprise both intraspecific crop diversity and total food plant diversity. Intraspecific diversity includes all food plants that have more than one recognized variant in the markets. We also analyzed market products that serve as propagation materials (e.g., seeds and other propagules).

We calculated food plant diversity for each market based on the Simpson Diversity Index (Magurran, 1991).

$$
D=1-\sum p i^{2}
$$

To calculate relative abundance (pi), we used data on the presence-absence of plant species in the inventoried stands (Evangelista et al., 2012):

where $p i=\frac{n i}{N}$

$n=$ number of stands per market where the species $i$ was recorded.

$N=$ number of all stands per market.

Then, we calculated the Simpson Diversity Index separately for farmers' recognized variants $\left(D_{\mathrm{FVar}}\right)$

where $p i=\frac{n i}{N}$

$N=$ number of all stands per market.

$n=$ number of stands per market where the variant $i$ was recorded,

as well as for species of the seed and plant propagation materials ( $\left.D_{\text {Prop }}\right)$

where $p i=\frac{n i}{N}$

$N=$ number of all stands per market.

$n=$ number of stands per market where the species of the seed and plant propagation materials $i$ was recorded.

We created a rank-frequency curve to show species distribution. Linear regressions of diversity parameters, market size, and the number of local merchants complement the results. Furthermore, we present clustering heat maps to visualize species composition within each market and show the similarity of species composition and distribution among the 10 markets. We used Ward's method algorithm and Euclidean distance measure. The heat maps were modeled with the "pheatmap" package in R 4.01 (https://cran.r-project.org/). 

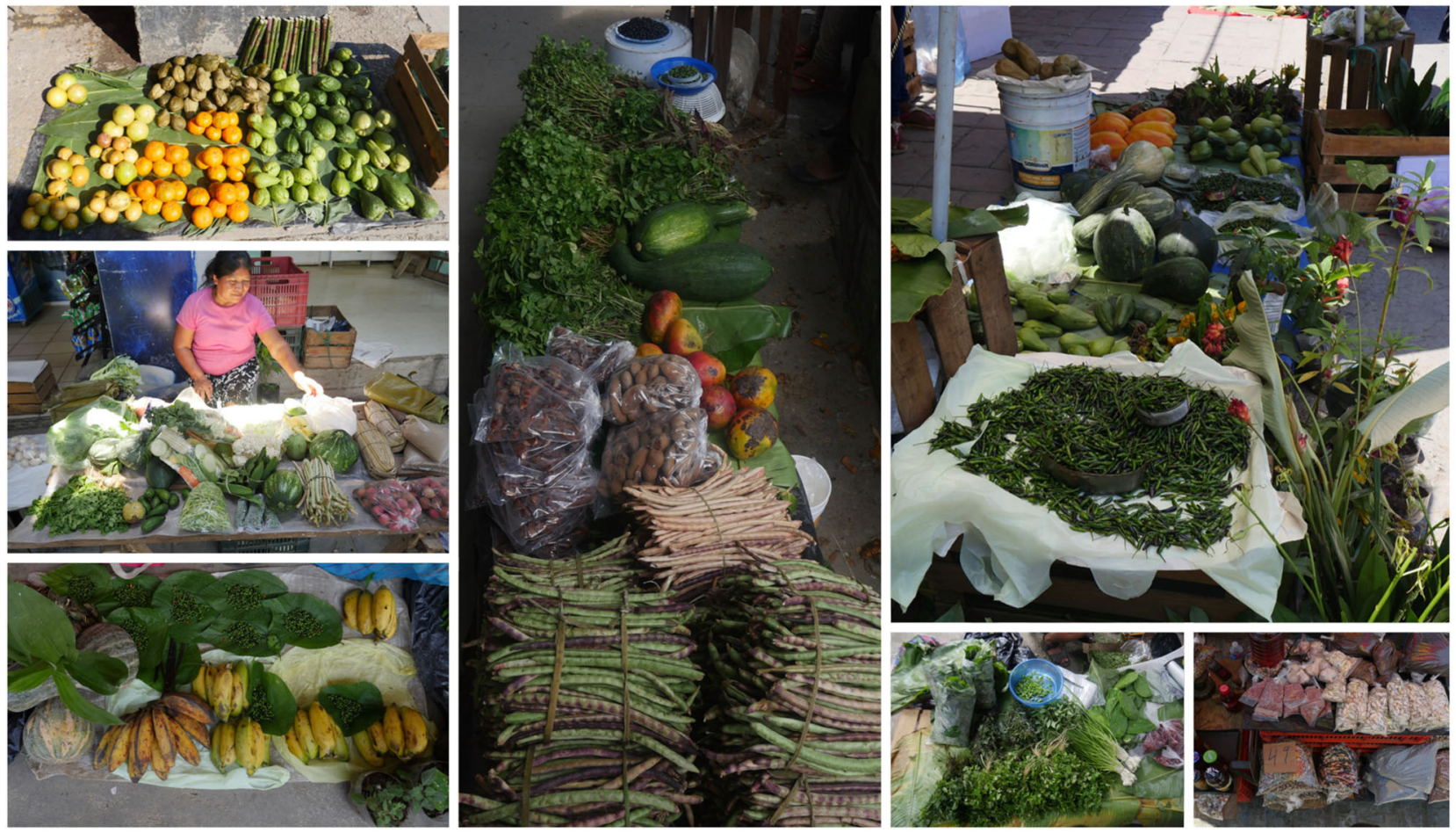

FIGURE 2 | Examples of stands with products offered by local merchants in the rural markets of the Huasteca Potosina.

Additionally, we used Sigmaplot 14.0 (https://systatsoftware. com/products/sigmaplot/) and Past 3.20 Software (https:// folk.uio.no/ohammer/past/) to calculate the diversity index and correlations.

\section{RESULTS}

In the Huasteca region, tianguis are local markets that operate on a rotating basis on separate days of the week in each location without competing with each other; on Sundays in the more important localities such as Ciudad Valles, and distributed over the rest of the weekdays in smaller places. In this regional market system, the most important local markets are centers for resource concentration and redistribution where products from different ecological zones converge. The smaller markets are less diverse and depend upon the more important ones for product provision.

Local markets are also called plaza, as they are often installed in the town's main square. In the Tének language, they are named bichow (lit. town, city) or nujumtaláb. Besides their importance for purchasing fruits and vegetables, markets are essential places to buy products that are not locally produced and thus connect with the globalized economic system. They are selling points for cheap, low-quality globalized industrial goods, such as sunglasses, jewelry, toys, music CDs, and plastic articles (Pérez Castro, 2005), presented next to traditional comales (clay or metallic griddles), candle holders, palm fiber fans, and other local handicraft products. Also, one can find stands with imported second-hand clothing and shoes, haberdashery products, or fabrics. Similarly, the agro-livestock sector offers local produce where people sell piloncillo (brown sugar), live birds, aromatic herbs, dairy products, and a great variety of chilis, among many other items (Pérez Castro, 2007). In small on street restaurants and stands on the market, women prepare traditional regional foods and beverages such as atole, sweet corn tamales, and zacahuil (the largest tamal of Mexico, of about 150-200 portions prepared as a special dish during festivities).

\section{General Description of the Local Markets}

The 10 markets are characterized by numerous stands with different products (Figures 1, 3). They have an average number of 252.1 stands, ranging from 70 in Tampaxal to 538 stands in Ciudad Valles, the biggest and most important market town in the Huasteca Potosina (Table 2). The others include marketplaces in municipal capitals but also a relatively large one in a village along the main road (Huichihuayán) and two more in smaller villages in remote areas (Tampaxal and Tamápatz). The highest proportion of stands include clothing, shoes, and accessories (20.5\%) (Figure 3). Still dominating the rural market character $(37.3 \%)$ are stands that offer agricultural goods (including products from local merchants, medicinal and ornamental plants, seasonings, coffee, and seeds). The average proportion of stands run by local merchants, who offer mainly local alimentary agricultural products, is $17.7 \%$. Stands with 


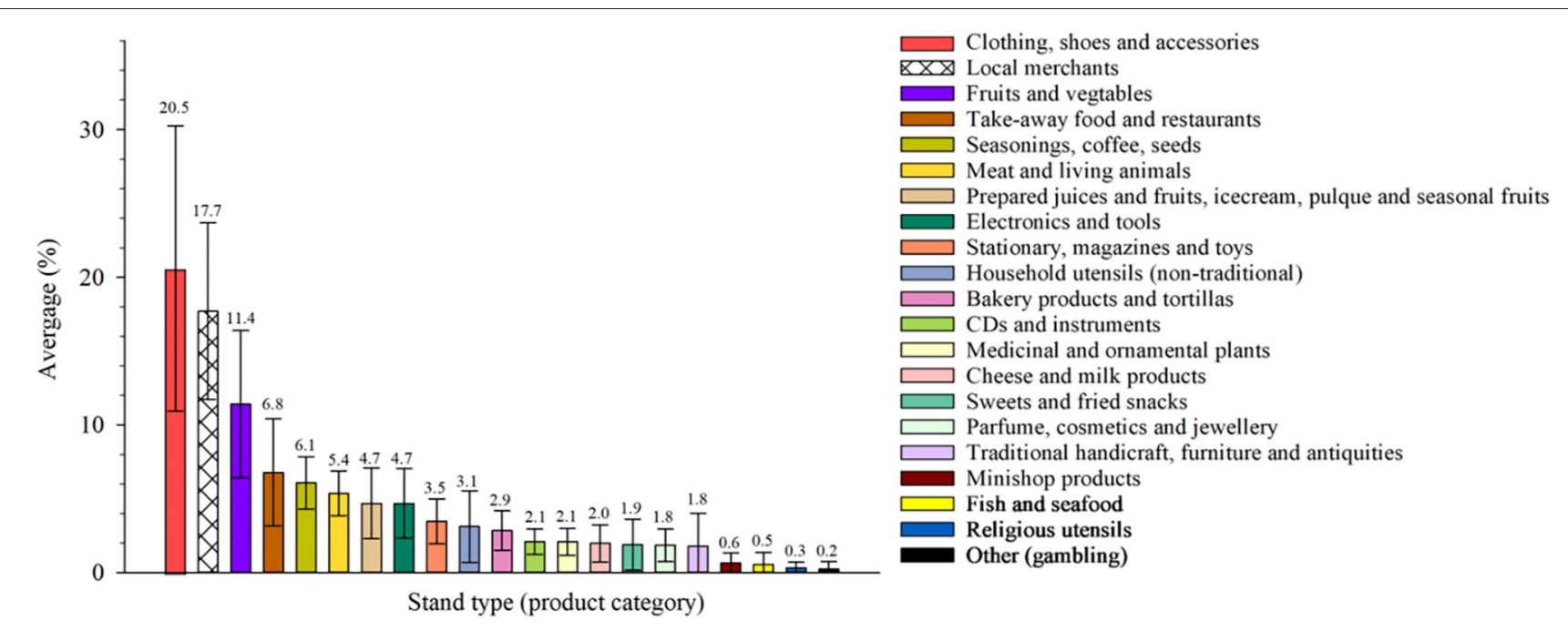

FIGURE 3 | Mean of the proportion (\%) of stand types in 10 rural markets in the Huasteca Potosina.

commercial fruits and vegetables, offered by non-local sellers, comprise $11.4 \%$. However, the high $\mathrm{SD}$-values indicate that market structure and composition vary from market to market. For example, in Aquismón, the proportion of local merchants is the lowest $(7.7 \%)$, whereas in Huichihuayán, the proportion of local merchants exceeds a quarter of all stands (25.6\%) (Figure 3 and Table 2). Regarding the proportion of local stands, linear regression shows a significant correlation between the number of total stands and the number of stands run by local merchants ( $R=0.89$ with $P<0.001)$.

\section{General Description of the Local Merchants}

The local merchants offering local agro-alimentary products have an average age of 48 years $(S D=16.1)$. Most of them are of Indigenous origin, with a majority of Tének (61.1\%), followed by Nahuas (31.3\%), and a minority is of non-Indigenous origin (7.6\%). The proportion of women is almost two-third (64.5\%) and the average distance from the merchant's community to the markets is $20.5 \mathrm{~km}(\mathrm{SD}=20.6 \mathrm{~km})$, ranging from $<1$ to $178 \mathrm{~km}$. On each market, the local merchants come on average from 12.3 $(\mathrm{SD}=5.2)$ communities. During one market day, each local merchant sells an average of $7.43(\mathrm{SD}=4.12)$ different products for a value of 674.0 MXN (28.2 US-Dollar) with an SD-value of 509.1 MXN and ranging from a minimum of $26 \mathrm{MXN}$ to 2,970 MXN. On average, the local merchants go out to sell 1.89 (SD = 1.72) times each week. Most of them (82.4\%) sell their products on one single weekly market. For the great majority of them, this is their only income opportunity (94.3\%).

\section{Food Plants Provenance}

Regarding the provenance of the recorded products, over three quarters $(77.3 \%)$ are cultivated by the local merchants themselves, which shows the predominance of direct marketing (Figure 4). The most important production systems are the milpas and home gardens, where almost two-thirds (66.2\%) of the products derive. Both systems are the principal production units for grains and regional staples. For example, most maize and bean variants are produced in the milpa fields. Maize, if not bought in other places, derives exclusively from the milpa fields (71.1\%), as well as $74.4 \%$ of all the bean species (Phaseolus spp. and $V$. unguiculata). Other species that are mainly produced in the milpas include vegetables like tomato (Solanum lycopersisum, 87.2\%), winter squash (Cucurbita moschata, 82.6\%), edible weeds like amaranth leaves (Amaranthus hybridus, 76.9\%), chilis (Capsicum spp. 55.9\%), and nopal cactus (Nopalea cochenillifera, 55.6\%).

Typical market products that are cultivated in the home gardens include regional staples like chayote (Sechium edule, 45.7\%) and fruits like banana and plantains (Musa sp., 50.8\%), and mango (Mangifera indica, 69.2\%). The teloms and fincas are the main suppliers of coffee (Coffea sp., 51.4\%) and more than $80 \%$ of the recorded wild chili species (C. annuum var. glabriusculum). Crops that are not very common in the region, like chard (Brassica oleracea, 95.5\%) or beetroot (Beta vulgaris, $80 \%)$, cultivated in more temperate zones, are purchased in other places outside the merchants' village or directly on the market from non-locals. The same applies to recently introduced crops like litchi (Litchi chinensis, 91.7\%).

\section{Local Merchants and Food Plant Diversity}

The total food plant diversity on the 10 local markets covers 275 plant types consisting of 99 different species. They include 65 plant species with no intraspecific diversity (only one variant) and 34 species with $\geq 2$ variants. The total number of variants that belong to species with intraspecific diversity is 210 . The average number of variants per species is 2.12 . Some species have a distinctly higher number of variants than average. These species include chayote $S$. edule, 51 variants), winter squash ( $C$. moschata, 25), mango ( $M$. indica, 12), and scarlet runner bean 
TABLE 2 | Inter- and intra-specific richness and diversity of local food plant diversity in 10 rural markets of the Huasteca Potosina.

\begin{tabular}{|c|c|c|c|c|c|c|c|c|c|c|c|c|c|}
\hline & Total & AQM & AXT & HUI & MAT & TMZ & TMC & TMX & $\mathrm{TCH}$ & VAL & XIL & Mean & SD \\
\hline \multicolumn{14}{|l|}{ Stands } \\
\hline Total & 2,521 & 326 & 124 & 170 & 273 & 110 & 238 & 70 & 242 & 538 & 430 & 252.1 & 147.6 \\
\hline Local merchants & 442 & 25 & 25 & 44 & 55 & 25 & 27 & 7 & 52 & 105 & 77 & 44.2 & 29.3 \\
\hline \multicolumn{14}{|l|}{ Richness } \\
\hline Total & 275 & 81 & 76 & 87 & 98 & 53 & 74 & 21 & 117 & 147 & 119 & 87.3 & 35.7 \\
\hline Plant species & 99 & 34 & 31 & 30 & 45 & 30 & 40 & 16 & 52 & 60 & 60 & 39.8 & 14.4 \\
\hline Intraspecific & 210 & 65 & 64 & 77 & 77 & 43 & 58 & 15 & 94 & 116 & 86 & 69.5 & 27.9 \\
\hline Propagation sp. & 58 & 18 & 14 & 20 & 24 & 17 & 24 & 10 & 31 & 35 & 37 & 23.0 & 9.0 \\
\hline \multicolumn{14}{|l|}{ Diversity } \\
\hline \multicolumn{14}{|l|}{ D-Simpson } \\
\hline$D_{\text {Total }}$ & & 0.98 & 0.98 & 0.98 & 0.98 & 0.98 & 0.98 & 0.95 & 0.98 & 0.99 & 0.98 & 0.98 & 0.01 \\
\hline$D_{\text {FVar }}$ & & 0.97 & 0.98 & 0.98 & 0.98 & 0.97 & 0.97 & 0.93 & 0.98 & 0.99 & 0.98 & 0.97 & 0.02 \\
\hline DProp & & 0.89 & 0.86 & 0.91 & 0.91 & 0.92 & 0.92 & 0.89 & 0.94 & 0.94 & 0.93 & 0.91 & 0.02 \\
\hline
\end{tabular}

$D_{\text {FVar, }}$ Farmer recognized variants; DProp, Plant species that are used as propagation material. SD, Standard deviation. Local markets: AQM, Aquismón; AXT, Axtla de Terrazas; HUI, Huichihuayán; MAT, Matlapa; TMZ, Tamápatz; TMC, Tampamolón Corona; TMX, Tampaxal; TCH, Tancanhuítz; VAL, Ciudad Valles; XIL, Xilitla.

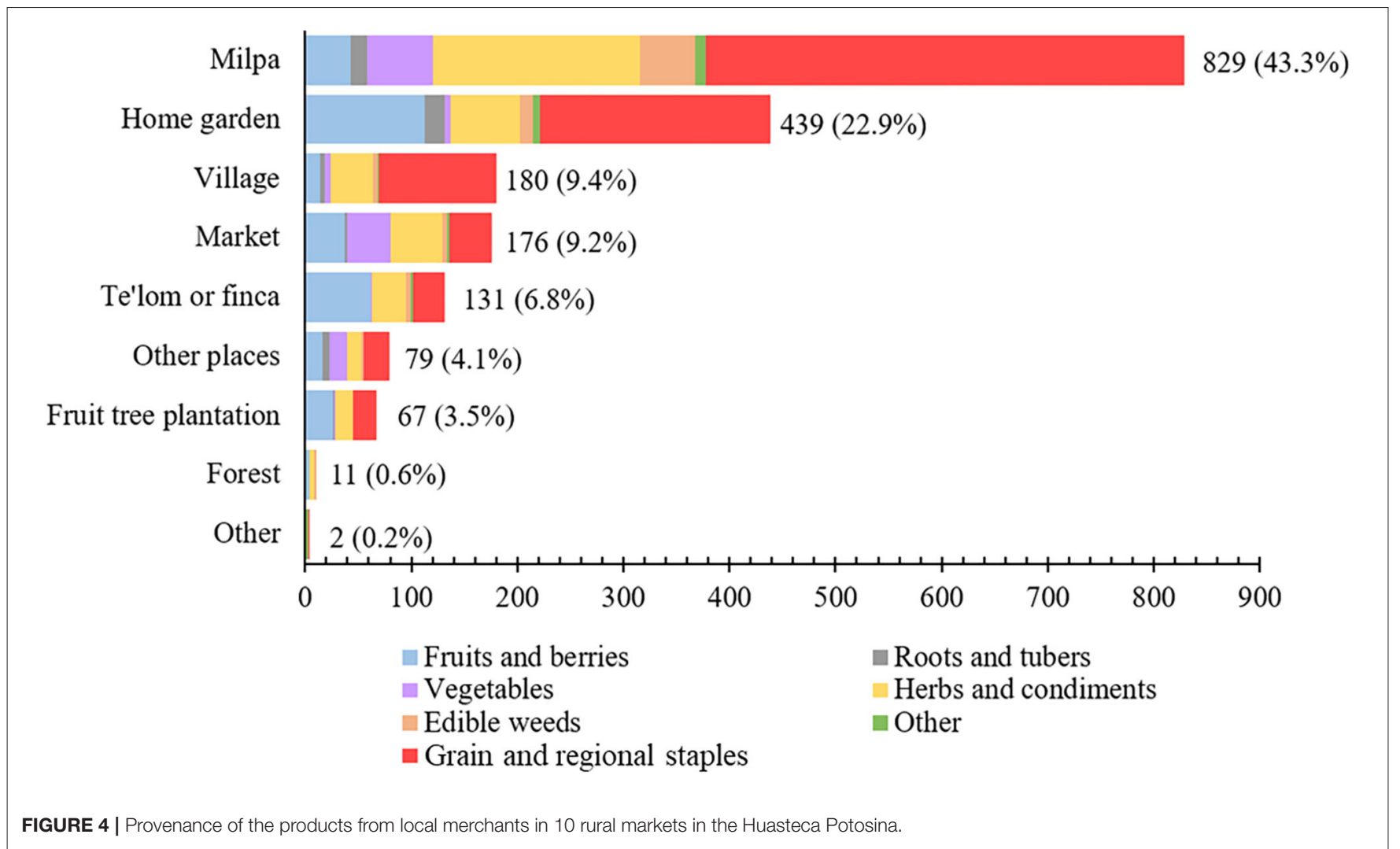

(P. coccineus, 11). Almost a third of all recorded plant species are fruits including berries (30.3\%), and a quarter belongs to herbs and condiments (25.3\%). We also recorded eight edible weed species (Figure 5A). Results differ when including the records of variants. In this case, grains, and regional staples (46.7\%) dominate the product range of the local merchants, followed by herbs and condiments (21.7\%), and fruits and berries $(16.4 \%)$ (Figure 5B).
The average number of total plant types recorded per market is 87.3. This includes an average of 39.8 plant species. Worth mentioning is the high average of intraspecific richness with 69.5 variants per market (Table 2).

The high SD-values and the fact that the markets differ in size and the number of local merchants (Table 2) lead to suggest a correlation between these parameters and richness measures. Indeed, there is a statistically significant correlation between the 
A

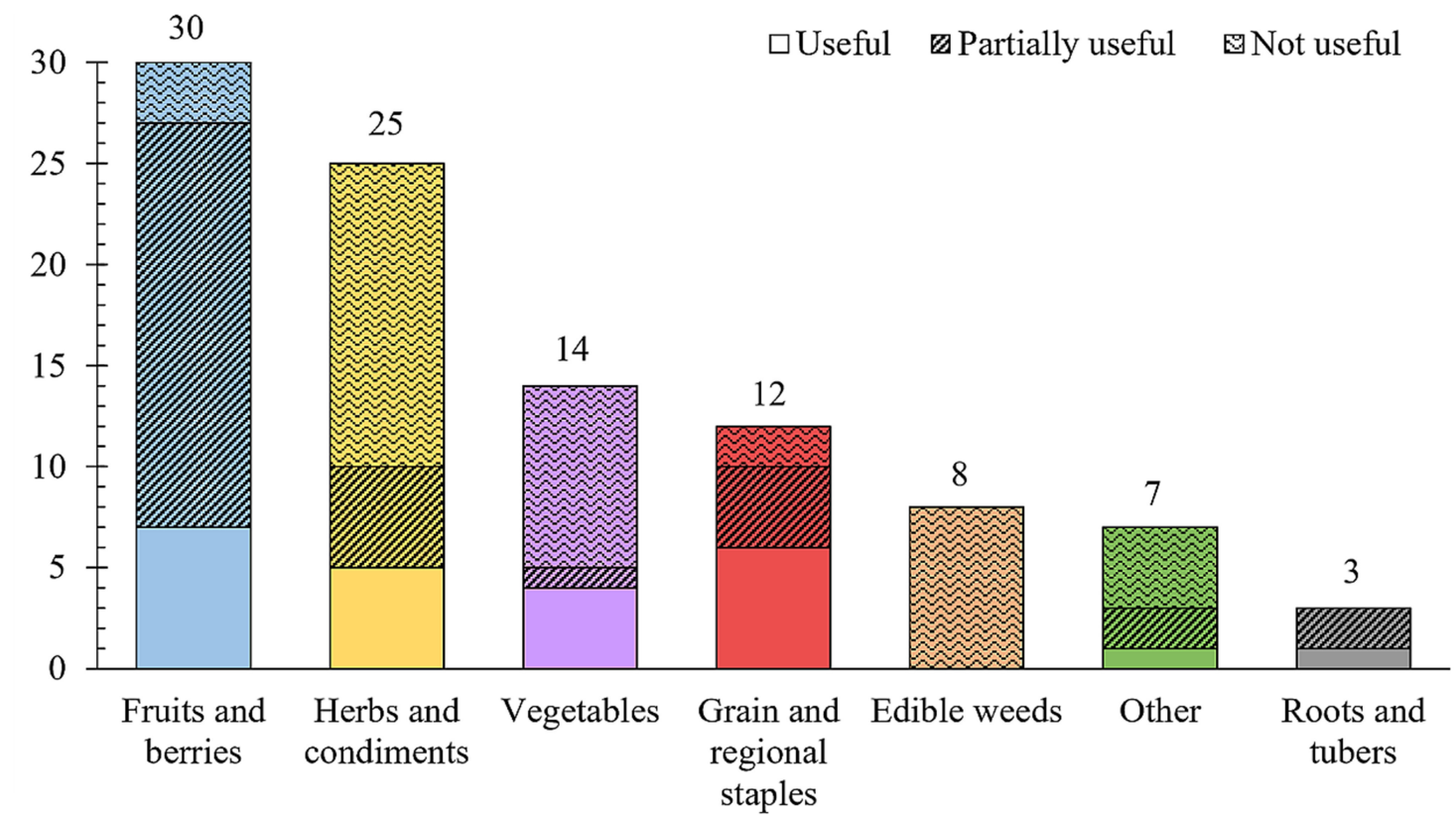

B

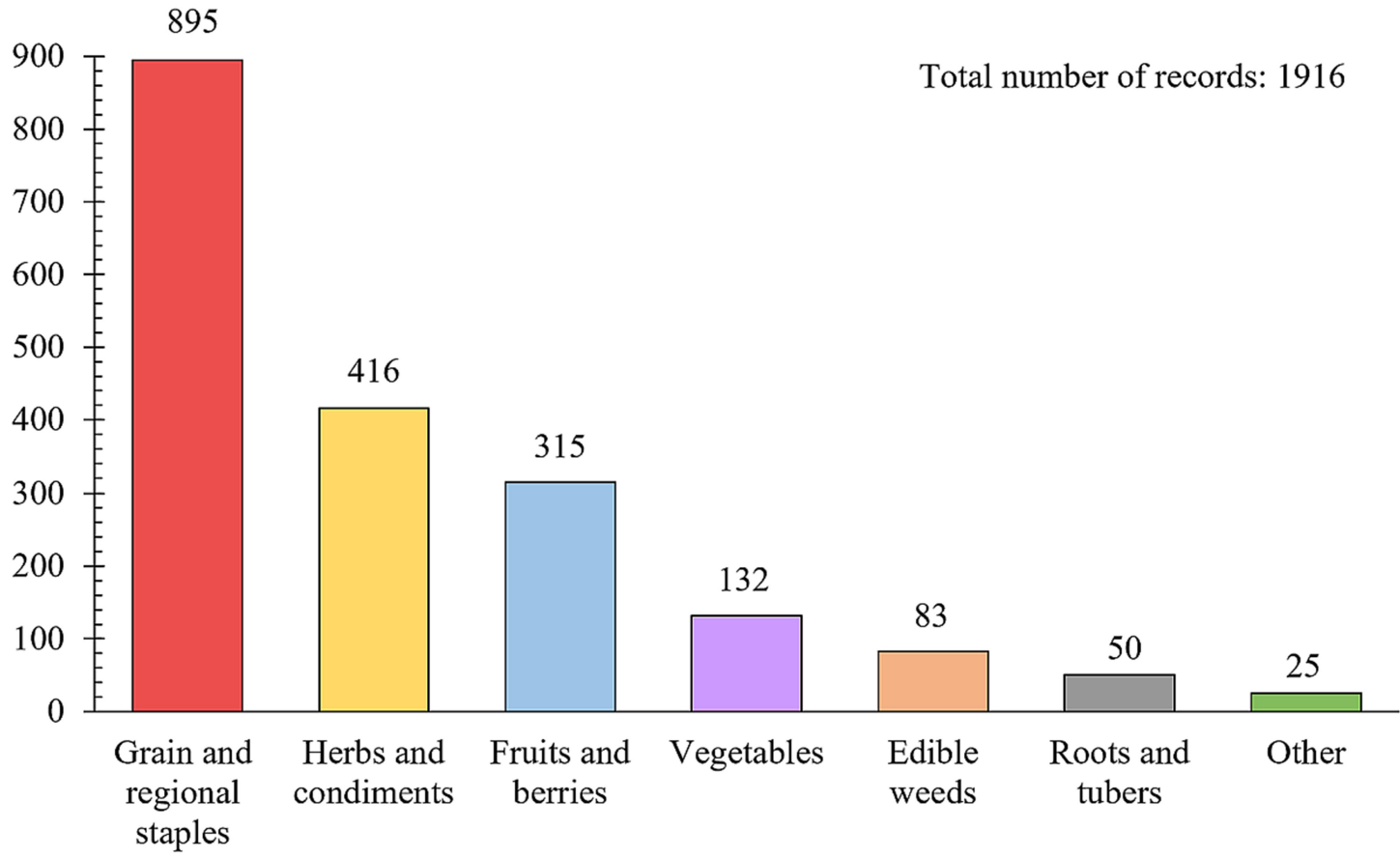

FIGURE 5 | (A) Usefulness of all documented plant species as propagation material. (B) Categories of edible plant species and variants from local merchants in 10 rural markets in the Huasteca Potosina. Note that the categories and grain and regional staples also include species like Sechium edule and Nopalea cochenillifera.

total number of stands (market size) and the total richness of food plants of the local merchants $\left(R^{2}=0.74\right.$ and $\left.P<0.01\right)$. The correlation is less strong for intraspecific richness $\left(R^{2}=0.64\right.$ and $P<0.01$ ) but is still statistically significant. However, bigger markets do not necessarily provide access to a greater number of plant propagation materials $\left(R^{2}=0.37\right.$ and $\left.P<0.1\right)$. Apart from market size, the number of local merchants is also related to the different richness parameters. A statistically significant and strong correlation exists between the number of local merchants and both the recorded total richness $\left(R^{2}=0.85, P<0.001\right)$ 


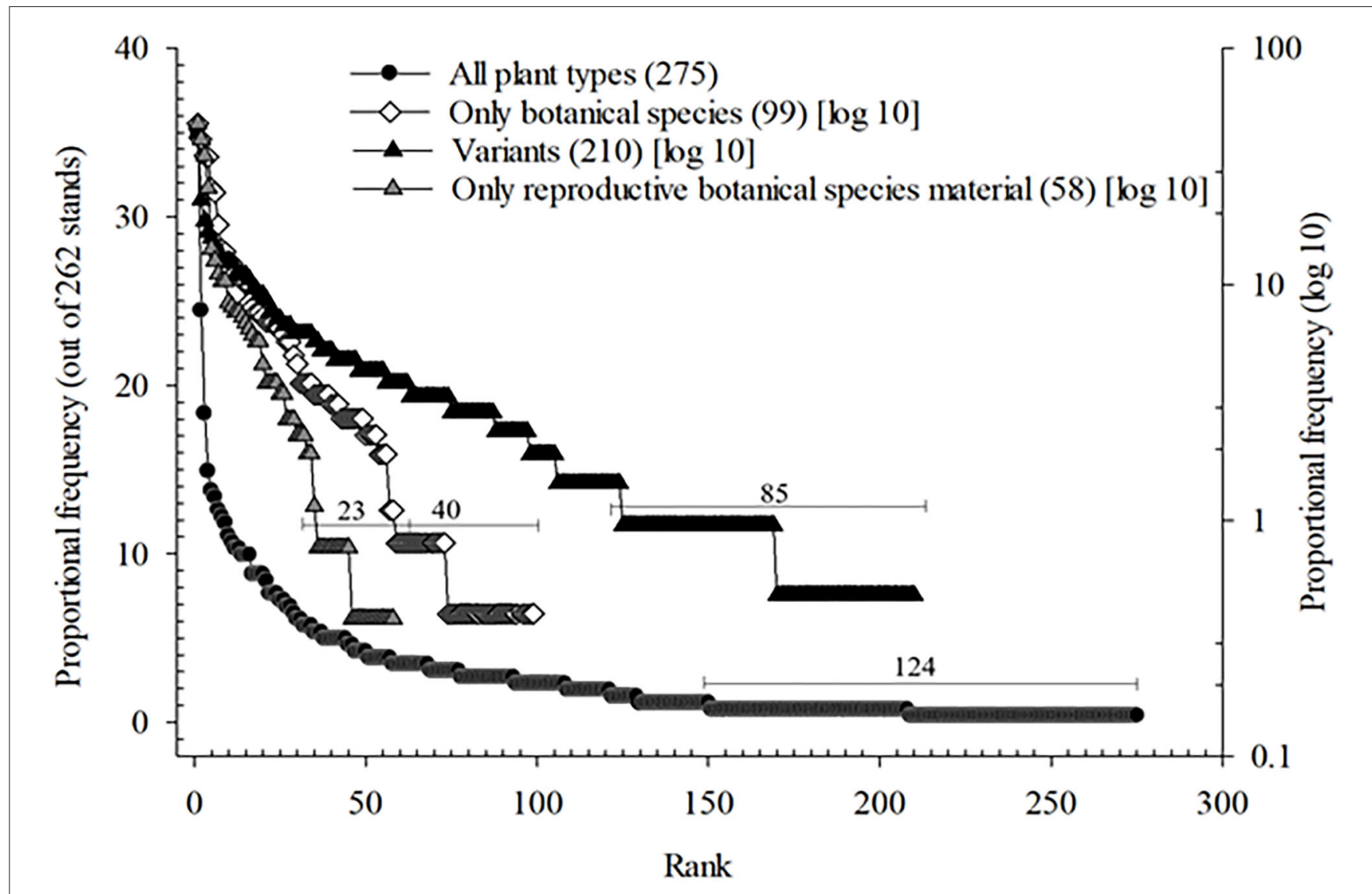

FIGURE 6 | Proportional rank-frequency curve of different richness parameters of the food plants from local merchants in 10 markets in the Huasteca Potosina.

and intraspecific richness $\left(R^{2}=0.80, P<0.01\right)$. The number of local merchants and the richness of seeds and plants used for propagation showed a lower correlation $\left(R^{2}=0.50, P<0.05\right)$. The number of different home localities of the local merchants and where they bring most of their products from does not correlate with the number of total richness $\left(R^{2}=0.27, P<0.2\right)$ nor with the propagative materials offered $\left(R^{2}=0.26, P<0.2\right)$.

The rank frequency curve demonstrates that almost half of all registered food plant types $(124,45.1 \%)$ was found in $<1 \%$ of the 262 inventoried stands. Concerning the diversity subclasses, $\sim 40 \%$ of the variants, botanical species, and species useful for propagation is offered by $<1 \%$ of the local merchants (Figure 6).

Of all recorded plant types, a few very frequent species and variants include the local coriander variant (Coriandrum sativum), found in more than a third of all stands (35.1\%), followed by mint (Menta aff. spicata, 24.2\%), bird chili variant (C. annuum, 18.3\%), and wild chili (C. annuum var. glabriusculum, 14.8\%). Regarding the species with propagation potential, S. edule (48.1\%) is the most representative species available on the markets, followed by coriander (C. sativum, $41.2 \%$ ) and chili (C. annuum, 35.1\%). Nopal (Nopalea cochenillifera, 34.7\%) is the most frequent species without propagation potential, for only its tender cladodes are sold.
A list of all recorded food plant species and variants is also presented in the heatmap cluster in Supplementary Material 1. The heatmap shows three main clusters and probably two reasons for their formation: market size and the local merchants' community of origin. The biggest markets, Ciudad Valles (VAL) and Xilitla (XIL), are clustered together as well as mediumsized markets like Tancanhuitz (TCH) and Axtla de Terrazas (AXT). However, one market, Aquismón (AQM), is very different in terms of its composition. This can probably be explained by the fact that most of its local merchants come from only one community, Jom te' Eureka, and these merchants were not present in the other markets. This would also explain why Tamápatz (TMZ), even though a relatively small market, forms part of the cluster of Xilitla and Ciudad Valles, because several of the local merchants who offer the products on these markets share the same community of origin. The heatmap also shows that only a few food plant species share a high abundance in almost all markets (e.g., S. edule) while many others have low abundance in each market and a low overall distribution (e.g., Ardisia venosa), which underlines the results of the rankfrequency curve. Interestingly, some exceptional cases occur, like the markets in Tampaxal (TMX) and TMZ, where S. edule and Coffea sp. were not recorded even though they are very frequent on all the other markets. 
TABLE 3 | Distribution of the food plant species useful for propagation in the markets in the Huasteca Potosina.

\begin{tabular}{|c|c|c|c|c|c|c|c|c|c|c|c|}
\hline & AQM & AXT & HUI & MAT & TMZ & TMC & TMX & $\mathrm{TCH}$ & VAL & XIL & Mean (SD) \\
\hline Plant species & 18 & 14 & 20 & 24 & 17 & 24 & 10 & 31 & 35 & 36 & $23.0(9.0)$ \\
\hline FSpe & 4 & 4 & 4 & 7 & 3 & 5 & 2 & 9 & 12 & 17 & $6.7(4.5)$ \\
\hline FVar & 53 & 61 & 66 & 64 & 34 & 45 & 10 & 81 & 98 & 72 & $58.4(23.5)$ \\
\hline Total $^{\star}$ & 58 & 65 & 70 & 71 & 37 & 50 & 12 & 90 & 110 & 89 & $65.1(28.2)$ \\
\hline \multicolumn{12}{|l|}{ Unique } \\
\hline FSpe & 1 & 2 & 2 & 1 & 23 & 3 & 2 & 3 & 8 & 9 & $5.4(6.4)$ \\
\hline FVar & 28 & 40 & 38 & 29 & 2 & 30 & 10 & 45 & 37 & 33 & $29.2(12.8)$ \\
\hline Total & 29 & 42 & 40 & 30 & 25 & 33 & 12 & 48 & 45 & 42 & $34.6(10.4)$ \\
\hline \multicolumn{12}{|l|}{ Rare } \\
\hline FSpe & 3 & 2 & 2 & 6 & 1 & 2 & - & 6 & 3 & 8 & $3.3(2.4)$ \\
\hline FVar & 21 & 20 & 27 & 33 & 8 & 14 & - & 34 & 60 & 39 & 25.6 (16.3) \\
\hline Total & 24 & 22 & 29 & 39 & 9 & 16 & - & 40 & 63 & 47 & $28.9(17.8)$ \\
\hline \multicolumn{12}{|l|}{ Common } \\
\hline FSpe & - & - & - & - & - & - & - & - & 1 & - & $0.1(0.3)$ \\
\hline FVar & 4 & 1 & 1 & 2 & 3 & 1 & - & 2 & 1 & - & $1.5(1.2)$ \\
\hline Total & 4 & 1 & 1 & 2 & 3 & 1 & - & 2 & 2 & - & $1.6(1.2)$ \\
\hline
\end{tabular}

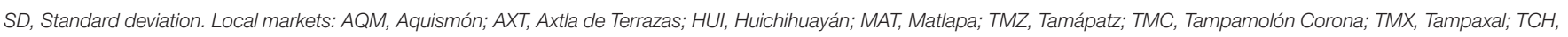
Tancanhuitz; VAL, Ciudad Valles; XIL, Xilitla.

FSpe, farmers' and merchants' locally recognized species with no documented intraspecific variation (<2 variants per plant species).

FVar, farmers' and merchants' locally recognized variants.

${ }^{*}$ FSpe + FVar, Total inter- and intraspecific food plant richness.

Unique, presence in one stand of the market, rare $=$ in $<30 \%$ of the stands per market, common $=$ in $30-60 \%$ of the stands per market.

The Simpson diversity index confirms and complements the aforementioned results (Table 3). The values are high, especially for the total of all edible plant types. It indicates that almost no dominant species or variants were inventoried. In the case of the diversity of species with propagation potential, the average value is slightly lower and can be explained by the fact that some species, for example, S. edule and C. moschata, are more frequent on each of the markets (see also Supplementary Material 1, Figure 7), which decreases species evenness.

\section{Diversity of Plant Propagation Materials}

More than 1,700 data points registered from food plant species and variants of 33 farmers in the region (Heindorf et al., 2019, in preparation) testify that almost half of them derived from the farmer's own stock (46.2\%), more than a third from different sources in the farmer's village (33.3\%), and $16.7 \%$ from outside the village. Most of the seeds and plants from outside the village were obtained from local markets (53.8\%), where local merchants were the main sources for seed and plant materials (92.9\%). The number of species obtained from local markets for propagation purposes was 50 . The species with the highest level of occurrences within this group include Phaseolus coccineus (36.7\%), Vigna unguiculata (36.0\%), Carica papaya (30.4\%), Persea americana (19.6\%), and Zea mays (17.0\%).

Our market inventory data show that not all products sold by the merchants serve as plant propagation materials. More than half of the 99 plant species recorded can be used partially $(27.7 \%)$ or in all cases $(30.3 \%)$ as plant propagation materials (Figure 5A). This depends mainly on the type of processing. For example, cooked chayote (Sechium edule) plants and fresh maize (Zea mays) cobs cannot be used for propagation purposes, whereas the uncooked chayote plants and dried maize seeds maintain their propagation potential, thus both species were considered as partially useful for propagation. The proportion of useful and partially useful material is highest for fruits and berries (90\%) and grains and regional staples (83.3\%). Edible weeds like Ipomoea spp. cannot be propagated (0\%) if purchased on the markets, neither can many vegetables and herbs and condiments (Figure 5A).

The average number of species useful for propagation per market is 23.0. The average intraspecific richness of 58.4 for these species clearly exceeds the number of 6.7 for species with no intraspecific diversity. The average number of unique species and variants with propagational use within the same market is 34.6. The number of rare species and variants is slightly lower with 28.9. Only a few common food plants (1.6) that can be used as plant propagation materials can be found in more than $60 \%$ of the stands from the local merchants (Table 3). The clustered heat map (Figure 7) illustrates which species with intraspecific diversity have the highest coverage on each market. It shows that only a few species, e.g., S. edule or C. annuum, are frequent and abundant on all the markets. An exception is the market of Tamapaxal (TMX), which does not show the presence of $S$. edule or a higher abundance of $C$. annuum, which explains why this market forms a completely separated cluster. It is also the market with the lowest total number of species with propagation potential and does not show a high number of variants. There are two other main clusters with up to five end groups. Each endgroup includes markets with similar species composition and species distribution. For example, the markets of Tamápatz 


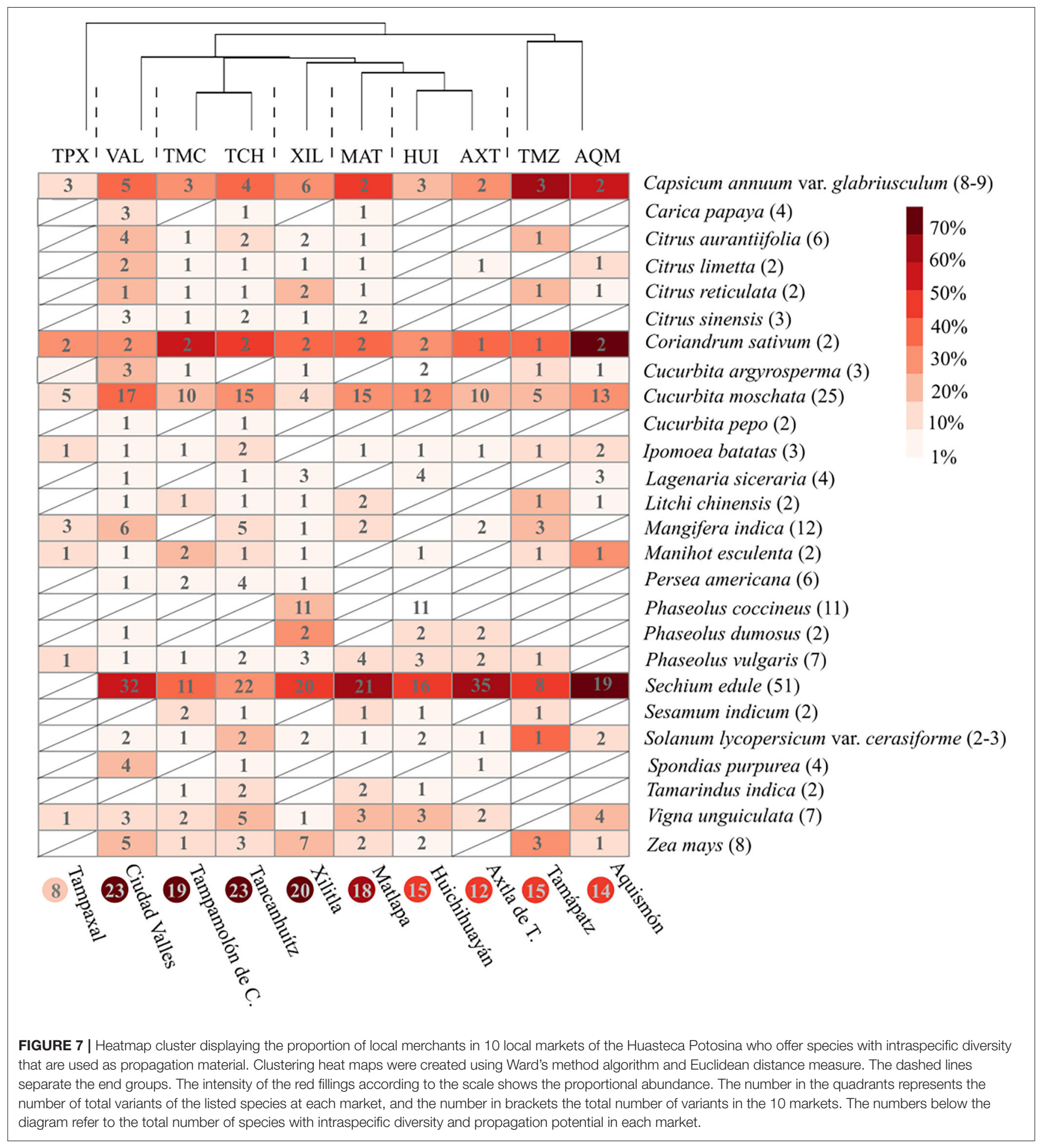

(TMZ) and Aquismón (AQM) share a high proportion of $C$. annuum. Huichihuayán (HUI) and Axtla de Terrazas (AXT) belong to the same end groups, as both markets have a lower richness and frequency of some fruit species (e.g., Citrus spp. and Persea spp.) and tubers (Manihot esculenta) but are the only places where all the bean species are available. However, the proportion of local merchants who offer $P$. dumosus and $P$. coccineus is highest for Xilitla (XIL). The other end groups of this cluster offer most of the propagation materials, ranging from 18 to 23 species. Moreover, it is shown that the biggest market, in Ciudad Valles (VAL), has the highest proportion (40\%) of local merchants who sell Cucurbita moschata. However, Figure 7 also 
demonstrates that the value of the proportional abundance of a species does not necessarily mean that the varietal diversity of the species is equally high. For example, Aquismón has the highest proportion of local merchants offering S. edule (71.4\%), but only 19 variants, whereas in Axtla de Terrazas chayote is offered by less local merchants, yet with a total of 35 recorded variants. A similar case is Ciudad Valles with 32 chayote variants. Results of linear correlations of the number of local merchants offering the propagation materials of a species with the total number of variants of this species show a statistically significant and strong correlation for $C$. moschata $\left(R^{2}=0.87, P<0.001\right)$, but not for chilies $\left(R^{2}=0.18, P>0.2\right)$ and chayotes $\left(R^{2}=0.33, P<0.1\right)$.

\section{DISCUSSION}

\section{Local Markets in the Huasteca Potosina as a Reservoir of Local Food Plant Diversity}

As in other parts of Mexico, the markets of the Huasteca (Supplementary Material 2) offer a wide range of different products without losing their original function, which is being a platform for local farmers to sell their agricultural surplus derived from a variety of land use systems (Figures 2, 3). We identified seven different food product categories offered by local merchants, consisting of healthy and diverse products. These are made accessible to the consumers and contribute to local food and dietary diversity and nutrition security (Ambikapathi et al., 2019). In this regard, it is worth mentioning that some of the recorded edible weed species are rarely found outside the local markets. These are often rich in healthy nutrients (e.g., $A$. hybridus, Rumex crispus) (Ranhotra et al., 1998; Akubugwo et al., 2007) but are usually not available outside the region, because they have to be consumed shortly after harvesting. Some of these edible weeds (long-shaped and round-shaped suyo, Ipomoea spp.) are culturally important but are poorly known and not consumed outside the research area. Even though it is often stated that access to and use of neglected and underutilized crops (NUS) contribute to a more secure food supply and poverty alleviation, detailed studies on their contribution to nutritional benefits and income generation are missing (Padulosi et al., 2002; Heywood, 2013). Filling these knowledge gaps is necessary to enhance policy engagement to support local markets that still provide access to a wide variety of food plants and income for small-scale farmers who produce them on their fields or recollect them from the wild environment.

Our results show that the swidden milpa is the land use system from which most edible plant products originate $(43.3 \%)$, followed by home gardens (22.9\%) (Figure 4). This is congruent with the results of a market study in central Mexico (ColinBahena et al., 2018). In the Huasteca Potosina, the proportion of stands run by local merchants (17.7\%) who offer food plants is higher than those of non-local merchants (11.4\%) (Figure 3). Most of their goods is self-produced, which contrasts with studies about markets in bigger municipalities and towns with more infrastructure and where the number of purchasing and reselling activities increases (Guadarrama Martínez et al., 2017; MartínezMoreno et al., 2019). Like in other parts of Mexico (e.g., Gómez
Sosa and Arellanes Cancino, 2018), the better part of the local merchant population is female $(64.5 \%)$.

The high proportion of local merchant population, mainly Indigenous, who offer products from their own land use systems may also explain why almost half of the recorded plant species (48\%) originated in the diversity centers and centers of domestication within the American continent, including Mexico. This is similar to the results from Whitaker and Cutler (1966), who, several decades ago, recorded a high proportion of New World plants (42\%) and native plants in the market of Tehuacan, Puebla, Mexico. For the markets in the Huasteca Potosina, this trend is ongoing. However, some important food crops did not originate in Mexico but are usually considered native and form part of the local food crop diversity. Those species include, for example, bananas and mangos, also frequently cultivated by the local people and with a high intraspecific richness.

In the Huasteca Potosina, the total species and variant richness of the food products from local merchants is high, counting 275 food plant types that belong to 99 plant species. These can be subdivided into 65 species with no intraspecific diversity and 34 species with intraspecific diversity. Other market studies in Mexico recorded between 59 and 106 plant species (Supplementary Material 2). Differences in sampling size (number of stands) and focus group (whether including nonlocal merchants or not) may explain the elevated numbers of some of these studies. For example, inventories of the food plant diversity from non-local merchants would include species like apples (Malus domestica) or grapes (Vitis vinifera), which are often brought from outside the region but not offered by the local merchants in the Huasteca Potosina, who focus mainly on locally or regionally produced fruits and vegetables.

The elevated number of variants shows the importance of intraspecific richness found at the local markets and was also reported by different authors for other markets in Mexico (Supplementary Material 2). Culturally more important crops in the region have a higher intraspecific richness. It is worth mentioning that the total number of chayote (S. edule) variants is 51, which exceeds by far the number reported in other studies. For example, Juárez Hernández et al. (2014) recorded 0-13 chayote variants in seven different markets in the Oaxaca Valley, which is known for its varietal diversity of this particular food crop. In our study, the number of variants is between 0 and 35 variants per market.

\section{Heterogeneity of Local Markets in the Huasteca Potosina}

The local markets differ in stand composition and structure. On average, 87.3 plant species and variants per market were recorded, but numbers vary considerably between the markets (Table 2). Bigger local markets offer a higher overall richness of food plant products. Further, the number of local merchants is positively correlated to the total richness as well. This should be taken into consideration to promote the participation of local merchants, who are the main contributors to the food product diversity and prevent a homogenization of markets and a dominance of "long-distance products" from outside 
the region, which is linked to the loss of crop diversity (Goland and Bauer, 2004). Access to markets is a well-known problem (Almekinders et al., 2009). In the Huasteca Potosina, infrastructure is challenging, and local transportation is often expensive. For example, local transportation costs are $\sim 200$ MXN to bring products to a market $40 \mathrm{~km}$ away, whereas local merchants sell an average of $509 \mathrm{MXN}$ per day. Strategies to provide accessible transportation during market days are needed to make local agrobiodiversity accessible to a broader population.

Nevertheless, the role of smaller local markets should not be dismissed. They are often located in remote areas, like the markets of Tamapaxal and Tamápatz, and are important access points to fruits and vegetables for marginalized communities. The number of unique species and variants does not depend on the market size, probably because merchants in smaller markets focus on more selective products to enhance the selling probability. Further, the high number of food species and variants that are presented in $<1 \%$ of the stands shows that every local merchant at each market contributes significantly to access to regional agrobiodiversity.

However, the number of different home localities of the local vendors is not positively correlated with the total richness of food plant products. The land use systems in the Huasteca Potosina are embedded in a highly heterogeneous landscape with significant differences in the crops cultivated within the same locality (Heindorf et al., 2019). This may also explain that product diversity on the marked is high, especially at the intraspecific level, even when farmers come from the same few villages. Yet, composition and abundance at the species level may be similar as shown in the case of the market in Aquismón. Here, most vendors are from the same locality and focus on species like the nopalea cactus ( $N$. cochenillifera) or coriander (C. sativum) (Supplementary Material 1), but rarely offer their products in other markets, a reason why this market was clustered separately.

As shown in Supplementary Material 1, species proportion per market is not necessarily an indicator for its intraspecific diversity. Some specialized local merchants bring many different variants of one species and can be considered key distributors of crop genetic diversity. For example, in Ciudad Valles, $<50 \%$ of the local merchants sold $S$. edule, but the intraspecific richness was considerably higher ( 32 variants) than in the market of Aquismon (19 variants), where more than $70 \%$ of the local merchants sold $S$. edule. Those key local merchants play a similarly important role as their counterparts in the field which refer to some very specialized farmers with a high number of variants of a particular crop (Heindorf et al., 2019).

\section{Local Markets and Access to Plant Propagation Resources}

Our results show that local markets in the Huasteca Potosina are crucial to access and use plant propagation materials, including 58 plant species. They constitute the most frequent source to obtain plant propagation resources outside the farmer's village. This evidences their important role as part of the informal seed system (Dalton et al., 2016; FAO, 2016;
Kansiime and Mastenbroek, 2016). According to Kansiime and Mastenbroek (2016) and FAO (2016), local markets are especially important to access bean and maize seeds, but less important to access vegetatively propagated crops. In the Huasteca Potosina, some bean species (e.g., P. coccineus $36.7 \%$, Vigna unguiculata 36.0\%) and maize seeds (Z. mays $(17.0 \%))$ are also frequently obtained from local markets, next to locally relevant fruits such as C. papaya (30.4\%) and $P$. americana (19.6\%). To a lesser extent, our list includes commonly vegetatively propagated crops like I. batatas $(4.1 \%)$ or Manihot esculenta (4.1\%) that are partially obtained from local markets.

Farmers' preferences for local varieties are strongly linked to their favorable features in taste and adaptation to the local agroecological conditions (e.g., Badstue et al., 2006; Sibiya et al., 2013). These preferences are not sufficiently acknowledged in formal breeding programs and the supply of improved or certified seeds. Hence it is not surprising that commercial seed production and supply play a minor role for small-scale farmers and subsistence farmers in the Global South (e.g., Almekinders et al., 1994; Poudel et al., 2015; McGuire and Sperling, 2016; Hoogendoorn et al., 2018). Even seeds for staples from formal suppliers and that are accompanied by efforts to promote commercial seed distribution constitute only a small portion of the farmers' seed materials (Louwaars et al., 2013; Coomes et al., 2015). For farmers in the Huasteca Potosina, the provision of commercial maize seeds is irrelevant, because most of them cultivate local crop varieties (Heindorf et al., 2019). If seeds or planting materials are acquired outside their village and not from their own stock, local merchants are the main important source (92.9\%), probably because goods offered by non-local merchants do not correspond to farmers' needs. At each market, we found an average of 58.4 variants of propagation materials, which underlines once more the significance of local markets to assure access to locally adapted and culturally accepted variants.

The overall food plant diversity used for propagation also includes neglected and underutilized crops (NUS). NUS are important at the local level but often lack presence in formal seed systems and are neglected in science and breeding efforts (Mabhaudhi et al., 2017). Yet, NUS have several advantages, such as better agro-ecological performance and a high nutritious value (Ebert, 2014). Their incorporation into the food system above the local level would also contribute to the diversification of a global food system that depends mainly on a handful of major food crops (the big three include rice, maize, and wheat), covering $\sim 90 \%$ of the daily calorie intake of the world's population (Monfreda et al., 2008). The FAO (2018a) recently recommended increasing the availability of high-quality seeds and planting materials of NUS. Besides the farmers' personal networks, local markets included in this study already provide this access to underutilized crop species like chayote and plums (Spondias spp.), including local variants that are not considered in the formal seed supply system in Mexico. The inventoried food plants also include species with recalcitrant seeds that are difficult to supply and cannot be conserved and stored by conventional methods such as drying or freezing. To this group belong, for example, the recorded P. americana and L. chinensis, as well as the 
underutilized crops that were mentioned before, like C. papaya and S. edule.

As shown by the different correlations, the number of plant propagation materials per market does not depend on market size, the origin of the merchants, or the total number of food plant richness of each market. However, as shown in Figure 7, each market provides a specific supply of seed and plant material in the region. We also recorded a high number of unique plant species and variants propagation materials within each market, and the rank-frequency curve (Figure 6) shows the same trend among all the different markets in the region. Hence, each local merchant is a valuable conveyer of local genetic resources to be passed to other local farmers who frequent these markets. Local markets facilitate open access to those resources to a broader public. In Mexico and other countries, access to local seeds is limited because they can often only be found in the local communities in remote areas. Markets are platforms outside the communities that link local producers and consumers from elsewhere, who may depend exclusively on these sources to gather locally adapted seed and plant material. Therefore, local markets should be considered an option to gather plant propagation materials for home gardens and agroecological projects in the region. Very often such projects are initiated by lifestyle migrants, i.e., people moving to places that are perceived to provide a better or different lifestyle (Santiago, 2017), who have not yet established a well-functioning seed network or seed stocks of their own.

Especially in tropical climates, seed storage is challenging, and markets can serve as backup access points when seeds are lost due to failure in storage. Likewise, they may play a vital role in disaster situations (e.g., after droughts, hail) to gather plant propagation materials when farmers' own stock is destroyed (McGuire and Sperling, 2013). During this present SARS-CoV-2 pandemic, local markets in the Huasteca Potosina were suspended or significantly reduced for several months. This may have three main market-related implications for the local people: reduced access to diversified food; shrunken income opportunities; and loss of access to seeds, as farmers who lost their seeds and cannot substitute this loss by accessing other sources within their villages will not be able to harvest in the following season. Until now, these are assumptions that should be investigated further. New insights on this topic are essential to guide political decision-making processes that respect both the immediate response to local health issues and the midterm and long-term response of the local food systems to crises. The decisions should take into account that local food production and their commerce in local markets provide income, genetic resources, and food, besides their cultural importance.

Local markets in the Huasteca Potosina are important components of the rural food system and farmer's seed network by providing income, access to a great variety of local foods, and access to seeds and plant materials for farming. They strengthen local propagation materials sovereignty and broaden the options to achieve nutrition and dietary diversity. The diversity made accessible by local merchants is high, especially at intraspecific level, and is partially correlated to other factors like market size and provenance. However, the high proportion of unique and rare food plants within and among the markets shows that food plant diversity in the local markets is not a guaranteed resource and may be threatened. To maintain and promote the use and conservation of this diversity in the future, political actions are needed, e.g., to support market access and rural infrastructure.

\section{DATA AVAILABILITY STATEMENT}

The raw data supporting the conclusions of this article will be made available by the authors, without undue reservation.

\section{ETHICS STATEMENT}

Ethical review and approval was not required for the study on human participants in accordance with the local legislation and institutional requirements. Written informed consent for participation was not required for this study in accordance with the national legislation and the institutional requirements. Written informed consent was obtained from the individual(s) for the publication of any potentially identifiable images or data included in this article.

\section{AUTHOR CONTRIBUTIONS}

$\mathrm{CH}$ conceived of the presented idea, conducted the fieldwork, and was responsible for research design and analysis. JAR-A and AH supervised project development and verified the analysis. $\mathrm{CH}$ provided a draft of the first manuscript and JAR-A and AH provided critical feedback and contributed to the final version of the manuscript. All authors contributed to the article and approved the submitted version.

\section{FUNDING}

This work was supported by a research grant from CONACYT (CB-2012-180863), a CONACYT scholarship for doctoral studies, and by the Autonomous University of San Luis Potosí through the Fondo de apoyo para la investigación (C18910 FAI-05-58.58).

\section{ACKNOWLEDGMENTS}

We thank our local experts Alejandra Balderas, Adriana Reyes, Ada Reyes, and Felipe Contreras for their collaboration with plant inventories at the local markets. We are grateful to the 262 interviewed local merchants who participated in this study. Special thanks to Agosto and Ike for their support during this research.

\section{SUPPLEMENTARY MATERIAL}

The Supplementary Material for this article can be found online at: https://www.frontiersin.org/articles/10.3389/fsufs. 2021.597822/full\#supplementary-material 


\section{REFERENCES}

Adhikari, J. (2014). Seed sovereignty: analysing the debate on hybrid seeds and GMOs and bringing about sustainability in agricultural development. For. Trees Livelihoods 12, 33-46.

Akubugwo, I. E., Obasi, N. A., Chinyere, G. C., and Ugbogu, A. E. (2007). Nutritional and chemical value of Amaranthus hybridus L. leaves from Afikpo, Nigeria. Afr. J. Biotechnol. 6, 2833-2839. doi: 10.5897/AJB2007.000-2452

Almekinders, C. J. M., Cavatassi, R., Terceros, R., Pereira Romero, R., and Salazar, L. (2009). "Potato seed supply and diversity: dynamics of local markets of Cochabamba Province, Bolivia: a case study," in Seed Trade in Rural Markets. Implications for Crop Diversity and Agricultural Development, eds L. Lipper, C. L. Anderson, and T. J. Dalton (Earthscan, FAO: London, Rome), 75-94.

Almekinders, C. J. M., Louwaars, N. P., and de Bruijn, G. H. (1994). Local seed systems and their importance for an improved seed supply in developing countries. Euphytica 78, 207-216. doi: 10.1007/BF00027519

Altieri, M. A. (2002). Agroecology: the science of natural resource management for poor farmers in marginal environments. Agr. Ecosyst. Environ. 93, 1-24. doi: $10.1016 / \mathrm{S} 0167-8809(02) 00085-3$

Ambikapathi, R., Gunaratna, N. S., Madzorera, I., Passarelli, S., Canavan, C. R., Noor, R. A., et al. (2019). Market food diversity mitigates the effect of environment on women's dietary diversity in the Agriculture to Nutrition (ATONU) study, Ethiopia. Public Health Nutr. 11:22. doi: $10.1017 / \mathrm{S} 136898001900051 \mathrm{X}$

Anderson, C. R., Bruil, J., Chappell, M. J., Kiss, C., and Pimbert, M. P. (2019). From transition to domains of transformation: getting to sustainable and just food systems through agroecology. Sustainability 11:19. doi: 10.3390/su11195272

Badstue, L. B., Bellon, M. R., Berthaud, Juárez, X., Manuel Rosas, I., Solano, A. M., and Ramírez, A. (2006). Examining the role of collective action in an informal seed system: a case study from the Central Valleys of Oaxaca, Mexico. Hum. Ecol. 34, 249-273. doi: 10.1007/s10745-006-9016-2

Bellon, M. R. (1996). The dynamics of crop infraspecific diversity: a conceptual framework at the farmer level. Econ. Bot. 50, 26-39. doi: 10.1007/BF02862110

Chable, V., Nuijten, E., Costanzo, A., Goldringer, I., Bocci, R., Oehen, B., et al. (2020). Embedding cultivated diversity in society for agro-ecological transition. Sustainability 12:3. doi: 10.3390/su12030784

Chappell, M. J., Wittman, H., Bacon, C. M., Ferguson, B. G., García Barrios, L., García Barrios, R., et al. (2013). Food sovereignty: an alternative paradigm for poverty reduction and biodiversity conservation in Latin America. F1000 Res. 2:235. doi: 10.12688/f1000research.2-235.v1

Cleveland, D. A., Soleri, D., and Smith, S. E. (1994). Do folk varieties crop varieties have a role in sustainable agriculture?. BioScience 11, 740-751. doi: $10.2307 / 1312583$

Colin-Bahena, H., Monroy, R., Velázquez-Carreño, H., García-Flores, A., and Monroy-Ortiz, C. (2018). El tianguis de Coatetelco, Morelos: articulador de la conservación biocultural en el territorio. Rev. Etnobiol. 16, 87-97.

Coomes, O. T., McGuire, S. J., Garine, E., Caillon, S., McKey, D., Demeulenaere, E., et al. (2015). Farmer seed networks make a limited contribution to agriculture? Four common misconceptions. Food Policy 56, 41-50. doi: 10.1016/j.foodpol.2015.07.008

Dalton, T., Anderson, C. L., Lipper, L., and Keleman, A. (2016). "Markets and access to crop genetic resources," in Seed Trade in Rural Markets: Implications for Crop Diversity and Agricultural Development, eds L. Lipper, C. L. Anderson, and T. J. Dalton (Earthscan, FAO: London, Rome), 15-27.

Ebert, A. (2014). Potential of underutilized traditional vegetables and legume crops to contribute to food and nutritional security, income and more sustainable production systems. Sustainability 6, 319-336. doi: 10.3390/su6010319

Ericksen, P. J. (2008). Conceptualizing food systems for global environmental change research. Glob. Environ. Change 18, 234-245. doi: 10.1016/j.gloenvcha.2007.09.002

Evangelista, H. B. A., Thomaz, S. M., and Evangelista, L. R. (2012). Comparison of diversity indices applied to macrophyte incidence-based data. Braz. Arch. Biol. Technol. 55, 277-282. doi: 10.1590/S1516-89132012000200014

Fanzo, J., Hunter, D., Borelli, T., and Mattei, F. (2013). Diversifying Food and Diets. London: Earthscan from Routledge.

FAO (2012). Seed System Security Assessment Report for Darfur Region. Rome: FAO.

FAO (2016). Seed Security Assessment: A Practitioner's Guide. Rome: FAO.
FAO (2018a). Scaling Up Agroecology to Achieve the Sustainable Development Goals: Proceeding of the Second FAO International Symposium. Rome: FAO.

FAO (2018b). Neglected and Underutilized Crops Species. Available online at: http:// www.fao.org/3/mx479en/mx479en.pdf (accessed August 02, 2020).

García López, V., Giraldo, O. F., Morales, H., Rosset, P. M., and Duarte, J. M. (2019). Seed sovereignty and agroecological scaling: two cases of seed recovery, conservation, and defense in Colombia. Agroecol. Sustain. Food Syst. 43:7-8. doi: 10.1080/21683565.2019.1578720

Goland, C., and Bauer, S. (2004). When the apple falls close to the tree: local food systems and the preservation of diversity. Renew. Agric. Food Syst. 19, 228-236. doi: 10.1079/RAFS200487

Gómez Sosa, L., and Arellanes Cancino, N. (2018). Del huerto al mercado: especies vegetales y comerciantes en la Villa de Zaachila, Oaxaca, Mexico. Rev. Mex. Agroecosistemas. 5, 43-54.

Guadarrama Martínez, G., Rubí Arriaga, M., Chávez Mejía, M. C., and de Jesús Sangermán Jarquín, D. M. (2017). "Conocimiento y usos de los frutos comercializados en el tianguis de Malinalco, Estado de México," in Calificación, Valorización y Turismo. Aproximaciones al Patrimonio Agroalimentario,eds H. Thomé-Ortiz and Á. R. Martínez Campos (Toluca: UAEM), 47-62.

Heindorf, C., Reyes-Agüero, J. A., and van 't Hooft, A. (in preparation). More than maize: inter- and intraspecific edible plant diversity in Huastec mayan landscape Mosaics in Mexico. Econ. Bot.

Heindorf, C., Reyes-Agüero, J. A., van 't Hooft, A., and Fortanelli-Martínez, J. (2019). Inter- and intraspecific edible plant diversity of the tének milpa fields in Mexico. Econ. Bot. 73, 489-504. doi: 10.1007/s12231-019-09475-y

Hernández-Rico, G. N., and Moreno-Fuentes, Á. (2010). Hongos comestibles del género Amita en el mercado de Acaxochitlán, Hidalgo, México. Etnobiología 8, $31-38$.

Heywood, V. (2013). "Overview of agricultural biodiversity and its contribution to nutrition and health," in Diversifiying Food and Diets: Using Agricultural Biodiversity to Improve Nutrition and Health, eds J. Fanzo, D. Hunter, T. Borelli, and F. Mattei (London; New York, NY: Earthscan from Routledge), 35-67.

Hoogendoorn, J. C., Audet-Bélanger, G., Böber, C., Donnet, M. L., Bisani Lweya, K., Malik, R. K., et al. (2018). Maize seed systems in different agro-ecosystems; what works and what does not work for smallholder farmers. Food Secur. 10, 1089-1103. doi: 10.1007/s12571-018-0825-0

Juárez Hernández, L. F., Campos Ángeles, G. V., Avendaño Arrazate, C. H., Enríquez del Valle, J. R., and Villegas Aparicio, Y. (2014). Conocimiento y comercialización de chayote (Sechium edule (Jacq.) Sw.) en los mercados de Valles Centrales de Oaxaca, México. Rev. Bras. de Agroecologia. 9, 90-103.

Kansiime, M. K., and Mastenbroek, A. (2016). Enhancing resilience of farmer seed system to climate induced stresses: insights from a case study in West Nile region, Uganda. J. Rural Stud. 47, 220-230. doi: 10.1016/j.jrurstud.2016.08.004

Linares, E., and Bye, R. (2016). "Traditional markets in Mesoamerica: a mosaic of history and traditions," in Ethnobotany of Mexico. Interactions of People and Plants in Mesoamerica, eds. R. Lira, A. Casas, and J. Blancas (New York, NY: Springer), 151-177.

Louwaars, N. P., and de Boef, W. S. (2012). Integrated seed sector development in Africa: a conceptual framework for creating coherence between practices, programs, and policies. J. Crop Improv. 26, 39-59. doi: 10.1080/15427528.2011.611277

Louwaars, N. P., and de Boef, W. S., Edeme, J. (2013). Integrated seed sector development: a basis for seed policy and law. J Crop Improv. 27, 186-214. doi: 10.1080/15427528.2012.751472

Lowder, S. K., Skoet, J., and Singh, S. (2014). What Do We Really Know About the Number and Distribution of Farms and Family Farms Worldwide? Background Paper for the State of Food and Agriculture 2014. ESA Working Paper No. 14-02. Rome: FAO.

Mabhaudhi, T., Chimonyo, V. G. P., Chibarabada, T. P., and Modi, A. T. (2017). Developing a roadmap for improving neglected and underutilized crops: a case study of South Africa. Front. Plant. Sci. 8:2143. doi: 10.3389/fpls.2017.02143

Magurran, A. (1991). Ecological Diversity and Its Measurement. Princeton: Princeton University Press.

Martínez-Moreno, D., Alvarado-Flores, R., Mendoza-Cruz, M., and Basurto-Peña, F. (2006). Plantas medicinales de cuatro mercados del estado de Puebla. Bol. Soc. Bot. Mex. 79, 79-97. doi: 10.18387/polibotanica.41.10

Martínez-Moreno, D., Reyes-Matamoros, J., Rivera-Mendoza, V., and BasurtoPeña, F. (2019). Análisis de las plantas comestibles, frutas y verduras, ofertadas 
en el tianguis de Tepexi de Rodríguez, Puebla, México. Polibotánica 48, 185-203. doi: $10.18387 /$ polibotanica.48.14

Maxwell, S., and Slater, R. (2003). Food policy old and new. Dev. Policy Rev. 21, 531-553. doi: 10.1111/j.1467-8659.2003.00222.x

McGuire, S., and Sperling, L. (2013). Making seed systems more resilient to stress. Global Environ. Change 23, 644-653. doi: 10.1016/j.gloenvcha.2013.02.001

McGuire, S., and Sperling, L. (2016). Seed systems smallholder farmers use. Food Sec. 8, 179-195. doi: 10.1007/s12571-015-0528-8

Meyer, R. S., DuVal, A. E., and Hensen, H. R. (2012). Patterns and processes in crop domestication: an historical review and quantitative analysis of 203 global food crops. New Phytol. 196, 29-48. doi: 10.1111/j.1469-8137.2012.04253.x

Monfreda, C., Ramankutty, N., and Foley, J. A. (2008). Farming the planet: 2. geographic distribution of crop areas, yields, physiological types, and net primary production in the year 2000. Glob. Biogeochem. Cy. 22, 1-19. doi: 10.1029/2007GB002947

Padulosi, S., Hodgkin, T., Williams, J. T., and Haq, N. (2002). "Underutilized crops: trends, challenges and opportunities in the 21st century," in Managing Plant Genetic Resources, eds. J. M. M. Engels, V. Ramanatha Rao, A. H. D. Brown, M. T. Jackson (Wallingford, CAB International and Rome, IPGRI Italy), 323-338.

Pérez Castro, A. B. (2005). Los "rancheadores": porteadores de mercaderías en la Huasteca. An. Antropol. 39, 89-117. doi: 10.22201/iia.24486221e.2005.2.9968

Pérez Castro, A. B. (2007). Contenidos de sabor para leer la historia y vida social de la Huaxteca. Itinerarios 6, 81-100. Available online at: http://itinerarios.uw.edu. $\mathrm{pl} /$ contenidos-de-sabor-para-leer-la-historia-y-vida-social-de-la-huaxteca

Poudel, D., Staphit, B., and Shrestha, P. (2015). An analysis of social seed network and its contribution to on-farm conservation of crop genetic diversity in Nepal. Int. J. Biodivers. 2015:1-13. doi: 10.1155/2015/312621

Ranhotra, G. S., Gelroth, J. A., Leinen, S. D., Vi?as, M. A., and Lorenz, K. J. (1998). Nutritional profile of some edible plants from Mexico. J. Food Compos. Anal. 11, 298-304. doi: 10.1006/jfca.1998.0590

Santiago, C. M. (2017). Lifestyle migration and the nascent agroecological movement in the Andean Araucanía, Chile: is it promoting sustainable local development?. Mt. Res. Dev. 37, 406-414. doi: 10.1659/MRD-JOURNAL-D-17-00036.1

Sibiya, J., Tongoona, P., Derera, J., and Makanda, I. (2013). Farmers' desired traits and selection criteria for maize varieties and their implications for maize breeding: a case study from KwaZulu-Natal Province, South Africa. J. Agr. Rural Dev. Trop. 114, 39-49.

Sperling, L. (2008). When Disaster Strikes: A Guide to Assessing Seed System Security. Cali: CIAT.

Sperling, L., Gallagher, P., McGuire, S., March, J., and Templer, N. (2020). Informal seed traders: the backbone of seed business and African smallholder seed supply. Sustainability 12:7074. doi: 10.3390/su12 177074

Sperling, L., and McGuire, S. (2010). Understanding and strengthening informal seed markets. Ex. Agric. 46, 119-136. doi: 10.1017/S00144797099 91074

Van der Veen, M. (2011). Consumption, Trade and Innovation: Exploring the Botanical Remains from the Roman and Islamic Ports at Quseir al-Qadim, Egypt. Frankfurt: Africa Magna Verlag.

Whitaker, T. W., and Cutler, H. C. (1966). Food plants in a Mexican market. Econ. Bot. 20, 1-6. doi: 10.1007/BF02861922

Conflict of Interest: The authors declare that the research was conducted in the absence of any commercial or financial relationships that could be construed as a potential conflict of interest.

Copyright (c) 2021 Heindorf, Reyes-Agüero and van't Hooft. This is an open-access article distributed under the terms of the Creative Commons Attribution License (CC $B Y)$. The use, distribution or reproduction in other forums is permitted, provided the original author(s) and the copyright owner(s) are credited and that the original publication in this journal is cited, in accordance with accepted academic practice. No use, distribution or reproduction is permitted which does not comply with these terms. 